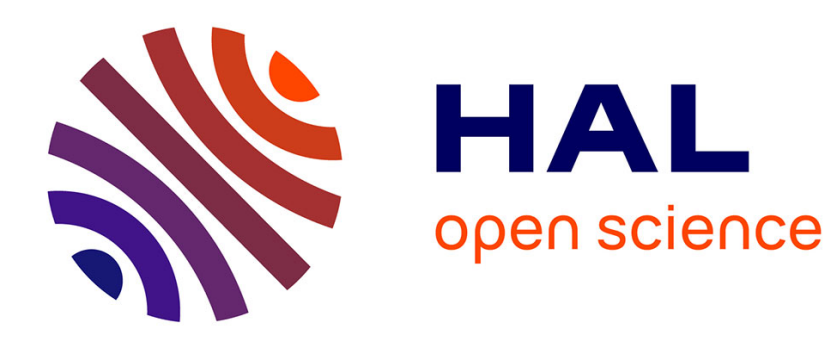

\title{
Expert groups in the field of eurocracy
}

Cécile Robert

\section{To cite this version:}

Cécile Robert. Expert groups in the field of eurocracy. Georgakakis, Didier; Rowell, Jay;. The field of eurocracy: mapping EU actors and professionals, Palgrave Macmillan, pp.137-165, 2013. halshs00951886

\section{HAL Id: halshs-00951886 \\ https://shs.hal.science/halshs-00951886}

Submitted on 25 Mar 2021

HAL is a multi-disciplinary open access archive for the deposit and dissemination of scientific research documents, whether they are published or not. The documents may come from teaching and research institutions in France or abroad, or from public or private research centers.
L'archive ouverte pluridisciplinaire HAL, est destinée au dépôt et à la diffusion de documents scientifiques de niveau recherche, publiés ou non, émanant des établissements d'enseignement et de recherche français ou étrangers, des laboratoires publics ou privés. 


\title{
Cécile Robert. Expert groups in the field of eurocracy. Georgakakis, Didier ; Rowell, Jay ;. The field of eurocracy : mapping EU actors and professionals, Palgrave Macmillan, pp.137-165, 2013. 〈halshs-00951886)
}

\author{
Expert groups in the field of Eurocracy
}

\section{Cécile Robert}

\section{Introduction}

The groups of experts of the European Commission have been, until recently, among the least visible actors of the government of Europe. Unlike the working groups of the Council (gathering representatives of the Member States and intergovernmental negotiations), or 'comitology committees' (consisting of officials from Member States assisting the Commission in its executive functions), these groups are solely accountable to the Community administration (de Maillard, Robert, 2008). Focused on preparatory and exploratory work, and composed of external actors with various statuses, these groups have a strictly consultative role. However, they are active in a crucial, yet weakly publicised phase of the European decision-making process: the preliminary stages of problem definition. Numbering approximately eight hundred in number, expert groups have rarely attracted the attention of the media, apart from a few notable exceptions, such as that for instance of the 'Sapir group' (Peuziat, 2005).

Nonetheless, in the Spring of 2009, they found their way into the media spotlight during highly publicised and heated exchanges between certain interest groups and the Community administration. The NGO Corporate UE Observatory, which has become visible over the past ten years through its crusades denouncing the power of business lobbies in the European political system, published a report on March 252008 suggestively entitled 'Culture of secrecy and companies' domination - a study of the composition and of the transparency of the Expert Groups in the European Commission' (Alter EU/CEO, 2008) ${ }^{1}$. Published by the ALTER EU network (Alliance for Lobbying Transparency and Ethics Regulation), the document analysed the composition of some forty expert groups. It simultaneously denounced the opaque operation of these authorities and the massive presence of representatives of industry, which was seen to produce both discreetly and efficiently a strong pro-industry bias in the European decision-making processes. If this controversy took place in series of public actions raising issues relative to transparency and the problematic relationships between the Commission and interest groups, it also echoed repeated complaints

\footnotetext{
${ }^{1}$ Expert groups has become one of the main focuses of the criticisms of Alter EU questioning the 'fair balance' of interests'. They published several reports: 'A captive Commission : the role of the financial industry in shaping EU regulation', Alter EU, 2009; 'Whose views count? Business influence and the European Commission's High Level Groups', Friend of the Earth Europe, 2009, 'Bursting the Brussels' Bubble', Alter EU, 2010 and in july 2012 : 'Who's driving the Agenda of DG enterprise and industry', Alter EU.
} 
from the European Parliament regarding the scarcity of information on expert groups ${ }^{2}$. The criticism was perceived as sufficiently significant to trigger a response from the Commission the following day via its spokesperson, Valérie Rampi, who emphasised the efforts to further transparency and balance to guarantee the independence of expertise elaborated within these groups.

These political skirmishes have brought to the fore questions on the roles and interests of the members of expert groups. More profoundly, they also raise questions on the social backgrounds, resources and positions of actors representing the 'European civil society' in the EU governance model (Michel, 2007). If the sociology of these types of actors has unsurprisingly remained a blind angle for political and media discourses, it is somewhat more puzzling that there has been little academic research seeking to characterize and closely study closely these groups (Georgakakis, 2009; Georgakakis, Weisbein, 2010). The first publications dedicated specifically to expert groups were indeed based on a macroscopic approach centred on the 'functions' fulfilled by the latter within the European institutional system (Larsson, 2003 ; Larsson, Murk, 2007). A more refined sociology of these actors seems necessary to complete this type of analysis, as it is difficult to analyse the political strategies conducted within or via these groups, without paying attention to the social resources of their members, which make these strategies or 'functions' possible in the first place. When research has looked at the composition of expert groups, it has been focused on the most visible attributes of these actors adopting the categories used by the European bureaucracy itself for describing them: academics, government officials, scientists, stakeholders, and so on (Gornitzka and Sverdrup, 2008a, 2008b, 2011). Although these studies can provide useful information to gauge the heterogeneity of this population united under the common denominator of 'experts', these elements mask the fact that these actors also share a collection of common properties as we will demonstrate in this chapter.

The purpose of this chapter is precisely to understand not only who European experts are, but also how they become and remain experts. Analysing the selection and selfpromotion processes of experts enables us to go beyond the duality of a functionalist or essentialist interpretation of expertise. Relying upon quantitative and, especially, qualitative data on the composition and functioning of expert groups (see text box below), we aim to identify the resources and the practices conditioning access and success in these functions. The goal is to better understand how and in which conditions expert authority can get the upper hand in policy arenas of the European field.

From this general perspective, we will first provide an overview of the sector of European expertise and its structuring principles. Highlighting the political uses of the groups enables us to explain the privileged recruitment of experts among certain categories of practitioners (academics, members of interest groups, national civil servants, and so on) (I) These political uses of expertise also contribute to promoting particular resources and practices, making it imperative to analyse the properties shared by the experts beyond their apparent heterogeneity. (II) A number of these properties are moreover acquired in the Community institutions, inviting to take a closer look at the way these expertise functions are embedded in professional careers and partake in the general cleavages of Eurocracy. (III)

\section{Text box 1: research methodology and data on expert groups}

Despite recent reforms, expert groups are difficult to observe and study. The constitution and the leadership of expert groups have indeed been considered as activities only governed by the

\footnotetext{
${ }^{2}$ The position advocated by the EP members on expert groups echoes the Alter EU's positions. Since 2010, a group of MEPs (mainly from the Greens and from the European United left) have asked several oral and written questions and used discharge procedures in 2011 and 2012 to push the Commission to increase transparency on the composition of expert groups.
} 
internal life of the Commission and was for a long time not perceived as an activity requiring accountability to the outside world. Since these activities are exerted in a decentralised fashion, most often at the levels of DG Units on the basis of very flexible administrative rules, record keeping on the activities of expert groups often existed only in departments, and in very disparate forms. It was only recently, in 2005, following a series of EP questions and following the line of administrative reforms initiated by the White Book on Governance (European Commission, 2001b), that a registry of these groups was prepared and made public (http://ec.europa.eu/transparency/regexpert/index.cfm). For the reasons mentioned above, the quality, coverage, and reliability of information was quite low until 2011 when a 2010 reform improved the quality of the register (European Commission, 2010). For these reasons and the plethora of existing groups (768 were listed in November 2012 on the site of the Commission), our research relies for the most part on qualitative data. The empirical research is centred on just over thirty groups registered in different Directorates-general and departments: General Secretariat; DG Employment, Social Affairs and Inclusion; DG Mobility and Transport; DG Education and Culture; DG Research and Innovation; DG Home Affairs; DG Agriculture and Rural Development; The Group of political advisers and the Bureau of European political advisers. Administrative sources were completed by eighty semi-directive interviews with civil servants in charge of composing and following expert groups as well as members of these groups.

\section{The Structuring Logic of European Expert Groups: When Expertise Absorbs Consultation}

In this first section, we would like to come back to the overarching structuring logics of European expert groups. We shall first of all touch on the rules governing their creation before going into more detail on their definition. The recruitment and composition of groups are viewed very directly through a 'consultative' lens. They are designed both as a prenegotiation tool and as the means of collecting resources useful to the decision-making process.

Initiated by the publication of the White Book on Governance, the recent reforms governing expert groups have given rise to vigorous reactions from different departments within the Commission. The groups are clearly perceived as one of the instruments and guarantors of the autonomy of the European administration. This perception has consequently lead to the idea that the creation of an expert group should not be rigidly regulated and be seen as instrument whose exact configuration should be determined on a case-by-case basis corresponding to the needs of the Commission. This flexible approach applies moreover to a decentralised practice as the vast majority of the groups are managed by units which are the lowest hierarchical level. As can be seen in the following text box, the only common formal feature of expert groups is a strict consultative function, and the fact that members are 'external' to the Commission.

\section{Text box $\mathrm{n}^{\circ}$ 2: The administrative framework of expert groups}

In the administrative texts governing the working of expert groups (European Commission $2002,2005,2010)$, they are mainly defined by their function and especially the explicit denial of decision-making powers. They are purely consultative authorities aiding the initiative work of the European Commission. As such, they are defined in contrast to the "comitology committees' (see above), to the social dialogue committees (which may prepare propositions for the Council), and to the so-called 'mixed' entities (derived from international agreements and designed for controlling implementation).

According to the Secretariat General of the Commission, an expert group is 'a body set up by the Commission or its departments to provide it with advice and expertise, comprising at least 6 public and/or private-sector members and meeting more than once. [They are set up] to provide 
advice and expertise to the Commission and its departments in relation to: the preparation of legislative proposals and policy initiatives (Commission's right of initiative); the preparation of delegated acts; the implementation of existing EU legislation, programs and policies, including coordination and cooperation with member countries and stakeholders in that regard. Expert groups are essentially a forum for discussions, providing high-level input from a wide range of sources and stakeholders in the form of opinions, recommendations and reports.' (European Commission, Secretariat General, 2012)

If some groups (estimated at fewer than 10 per cent of groups in activity) may be subjected to a formal decision of the College, most are appointed by departments (General-Directorates), with the (quasi systematic) agreement of the Secretariat-General. This distinction, no more than that between permanent groups (created by a formal act or over 5 years) and temporary groups, is not reflected by specific recruitment rules and practices.

It should be mentioned finally, as we will see further on, that experts belonging to national administrations or certain interest groups, may, under certain configurations, be designated by their own organisations and institutions. In this (frequent) case, the departments of the Commission first specify the administrations and groups, and ask them to send, depending on the subject, the person whom they deem the most competent.

This flimsy administrative framework and the ad hoc character of the composition of these groups are in line with one of the principles guiding these practices: the management, during the expertise procedures, of the logic of consultation of 'interested parties'. In other words, if each of the expert groups incarnates this combination to various degrees, their common feature is to claim double legitimacy for their expertise: that of a specialised knowhow intended to aid decision making, and that of a viewpoint representing the public that may be affected by the issue being discussed. The presentation made by the Secretariat General in various documents (and notably its website) is quite explicit on this point: 'The composition of a group varies according to the type and the field of application of the expertise sought after. The score of knowledge provided to the Commission should not only be excellent from a scientific viewpoint, it should also be in keeping with practical, legal, social, economic and environmental considerations; consequently, numerous groups include not only scientists but also executives from the public and private sectors and other similar actors.'(European Commission, Secretariat General, 2008)

This definition of expertise is meaningful in light of the political issues associated with this form of consultation (Robert 2009, 2010a). Since 2000, it has been the focus of an institutional discourse that aims to use expert groups as a means to demonstrate the openness of the Commission to civil society and the democratic character of its decision-making processes. If the argument is not new, it has benefited from more precision and increasing publicity since the White Paper on Governance was published (European Commission, 2001b) $)^{3}$. Several documents (European Commission, 2001a, 2002) have contributed to formalising a definition of expertise explicitly as representative in two complementary ways: the first argues that that it is necessary to avoid reducing expertise to a conventional scientific knowledge corpus by bringing in other 'concerns, i.e. other 'points of view' to make policy more 'socially robust'; the second argument sees the very process of expertise as a tool to restore trust and strengthen the ties with civil society.

These symbolic issues also relate to practical concerns. For the officials of the Commission, forming an expert group often aims at collecting information susceptible to improve the wording of Commission texts and, in particular, to provide better knowledge on the area of proposed action. Whether this involves taking stock of the existing provisions in national legislations, surveying the socio-economic situation of a given category of population in the different Member States, or drawing conclusions on the different

\footnotetext{
${ }^{3}$ For an analysis of the uses of the White Paper on Governance see (Georgakakis, de Lassalle 2011)
} 
manufacturing methods of given industry, setting up a consultative procedure is also, intrinsically, a means for Euro-officials to test the social and political acceptability of their initiatives (Robert, 2010a). By facilitating forms of consultation beforehand, Commission officials can identify possible sources of opposition and integrate these constraints into policy proposals and better anticipate potential problems of implementation at the national level. The exchanges and the opinions voiced in the group are thus often presented as potential arguments meant to convince reticent actors or institutions (Parliament, Council, particular Member States, interest groups), in particular when these are 'represented' within the expert groups. In addition, the obligation imposed to the departments since 2004 to provide, for each act of the Commission, an impact study (part of the 'better regulation' reform initiated in the European Commission (2002b)) has encouraged the implementation of consultation with different actors affected. On the other side, potential 'experts' closely monitor activities in relevant DGs. While bearing in mind that these logics are diverse, and that they are individual as well as institutional and collective, they also tend to turn these groups into a place for prenegotiation. For the experts interviewed, the purposes are manifold: to make oneself heard very early in the reflection process of the Commission; to better understand the positions of competing organisations or of institutional partners; to make use of the presence of representatives from Member States to get them to commit to a point of view; to highlight gaps in the implementation of a European guideline, and so on.

Regardless of the respective political or technical aspects of the expertise being sought, each recruitment is thought of, and performed as choosing both a representative and an expert. This particular view of expertise leads break with a common conception of experts as the recognized holders of specialized scientific knowledge in a particular domain. This type of expert knowledge is neither a prerequisite nor even a widely shared property. The 'knowledge' or the 'expert' skills sought after in this procedure are far from being limited to academia and are in fact highly dependent on the expert belonging to different national, professional or activist 'collective bodies'. To give just one illustration, one can cite the grounds for which the members of the high level group on 'social integration of the ethnic minorities and their full participation to the labour market' were appointed. According to Commission, Louis Schweitzer (a former CEO of Renault) was appointed on the basis of his responsibilities in the Halde (French High Authority against Discriminations and for Equality); Lee Jasper as Councillor for ethnic issues to the Mayor of London; Jarmila Balážová, because she belongs to the Rom community and hosts a radio programme dedicated to them; or Rita Süssmuth, former president of the Bundestag, and former Minister of Family, of Feminine Condition, of Youth and Health, on grounds in particular of her participation in various national and international commissions on migratory issues.

Finally, if these experiences often replace academic diplomas, they may conversely devalue a candidacy, or even bar recruitment altogether. An emblematic example is provided by nationality, which may be a considerable asset or handicap for an individual, as geographical representation is often an important factor: 'A geographical balance is still necessary, i.e. having Northern Member States only is not acceptable. Scandinavian countries are known to possess very close legal systems, so if we do not have a representative from each of the three countries, it is not critical, but we must have at least one Scandinavian ... A Common Law is necessary, the new Member States must participate; we cannot have all ten of them, but at least two or three... There are States which are still powerful in terms of votes in the Council, whereas if Lithuania does not agree, well you know how it is ... ${ }^{\text {, (Interview }}$ with an official of the DG Home Affairs, April 2008)

Far from following a unique model, the expert groups studied within the framework of this investigation display a wide diversity in their configurations which depend on the political uses intended by the departments at the moment of their creation. They can however 
be distributed around different poles, corresponding to partially differentiated logics of recruitment. A first axis consists of the contrast between groups expected to be true initiators and those playing a more symbolic role. Along a second axis, the groups are apportioned according to the nature of issues under discussion: from the more 'technical' ones requiring specific knowledge to issues most explicitly centred on determining what is feasible politically and structured by a logic of consulting representatives from national administrations and interest groups to determine the levels and sources of support or opposition to a given project ${ }^{4}$.

Groups may be positioned in each of these quadrants, even if a number of groups may, depending on the context, move from one quadrant to another. With regard to groups that are less associated with the preparation of the legislative proposals initiated by the Commission than to their legitimisation, an authority such as the Michalski group, formed under Romano Prodi's presidency and working with the group of the political advisers to 'demonstrate the Commission's interest' in issues relating to the cultural and spiritual dimension of Europe, may be mentioned as closer to the 'political' pole. Closer to the technical pole, one may think, for instance, of a series of groups composed mostly of academics which are presented, for example by the DG Employment, as having a 'theorising' and 'formalising' role of the initiative engaged by the Commission in a given area.

Close to the initiation function and on the 'technical' pole, we can cite groups associated in the writing process of proposals such as a group of experts composed of a handful of specialists from the public and private sectors for advising the DG Mobility and Transport on the methodology to improve knowledge on road accidents. With regard to the political side, we can identify expert groups composed primarily of representatives from national administrations, for examining the DG Home Affairs exploration of the opportunity to harmonize national legal provisions regarding the 'patrimonial effects of marriage'.

Specifying the polarities structuring the field of European expertise enables us to understand why the members of these authorities are mainly recruited in three broad categories (see tables below) : the academic world, national administrations, and 'organized civil society’ covering organisations representing public and/or economic interests.

Table $\mathbf{n}^{\circ}$ 1: Participation in expert groups of the Commission per categories of actors

\begin{tabular}{|l|l|l|}
\hline $\begin{array}{l}\text { 'Categories' of members of } \\
\text { expert groups }\end{array}$ & $\begin{array}{l}\text { Number of expert groups in } \\
\text { which the category is present }\end{array}$ & $\begin{array}{l}\text { In proportion to the number } \\
\text { of expert groups listed in the } \\
\text { registry } \\
\text { (N=1237) }\end{array}$ \\
\hline National administrations & 864 & $69.8 \%$ \\
\hline Competent national authorities & 422 & $34.1 \%$ \\
\hline Academics/Scientists & 412 & $33.3 \%$ \\
\hline Industry/ Companies & 352 & $28.5 \%$ \\
\hline NGOs & 207 & $16.7 \%$ \\
\hline Professionals & 157 & $12.7 \%$ \\
\hline Social partners/ Unions & 146 & $11.8 \%$ \\
\hline Regional and local authorities & 100 & $8.1 \%$ \\
\hline Consumers & 96 & $7.8 \%$ \\
\hline International organizations & 27 & $2.2 \%$ \\
\hline
\end{tabular}

\footnotetext{
${ }^{4}$ The purpose here is obviously not to oppose technical and political expertise as if it were possible to clearly distinguish between hermetic categories. In reality, 'political' or 'technical' issues refer to the way they are treated, prepared and represented at certain moments of the decision-making process, which means that the same issue and hence the same group may move along this axis at different stages of the policy sequence.
} 
Table $\mathbf{n}^{\circ}$ 2: Principal 'configurations' of expert groups

\begin{tabular}{|l|l|}
\hline Types of composition of the groups & $\begin{array}{l}\text { In proportion to the number of expert groups } \\
\text { listed in the registry }\end{array}$ \\
\hline National administrations & $26 \%$ \\
\hline $\begin{array}{l}\text { National administrations and competent national } \\
\text { authorities }\end{array}$ & $11 \%$ \\
\hline Competent national authorities & $6 \%$ \\
\hline Scientists & $5 \%$ \\
\hline NGOs, social partners, industry and consumers & $3 \%$ \\
\hline Industries & $2 \%$ \\
\hline $\begin{array}{l}\text { National administrations and competent national } \\
\text { authorities and industries }\end{array}$ & $2 \%$ \\
\hline $\begin{array}{l}\text { National administrations and local and regional } \\
\text { governments }\end{array}$ & $2 \%$ \\
\hline National administrations and scientists & $2 \%$ \\
\hline Scientists and industries & $1 \%$ \\
\hline Sub-total & $61 \%$ \\
\hline
\end{tabular}

\section{Source: Gornitzka and Sverdrup, 2008a}

*: The data used are extracted from the on-line registry of the Commission on the site of the General Secretariat. On this basis, the researchers have simply performed two types of calculations: for each 'category' the percentage of groups in which it was represented; the identification of 'types' of group composition. These categories used in the tables are those of the register, (they was not constructed for the purpose of the study).

**: Inasmuch as the registry does not specify which proportion of each category forms the group, table $n^{\circ} 1$ does not differentiate between expert groups where the category is represented by one expert only and groups composed almost exclusively of members of the category.

If the tables provide a first picture of the European expertise field, they nevertheless raise several issues. In addition to the poor reliability of the data available from the online registry (no updates, gaps, and so on), the categories are unfortunately neither homogeneous nor clearly defined: for example, 'academics' are classified separately from 'members of national administrations', whereas in a number of Member States both 'statuses' often go hand in hand; 'academics' are also differentiated from 'scientists', a designation for actors coming from public research as well as R\&D departments of companies. But these forms of differentiation mask properties shared by the experts. It is precisely this aspect which we will now consider.

\section{Social properties of experts and the efficient resources in the field of European expertise}

If the institutional design of expertise follows the principle of differentiating among actors in order to demonstrate the inclusion of all pertinent points of view, it also contributes, for the same reasons, to building the expertise itself in these groups as a particular form of interest representation. It tends to promote experts as facilitators of compromise, which has effects on the importance given to certain social practices and properties compared to others (Nay, Smith, 2002). If these qualities do not constitute a prerequisite per se for an actor to be named as an expert, they strongly condition his or her success in this role and legitimacy in the group. 


\section{International openness}

A first set of properties evident in expert groups pertains to 'international openness' (Dauvin, Siméant, 2004). On this aspect, the logics operating in this arena are in line with those in other areas of European field, such as top civil servants (see chapter 2), MEPs (see chapter 1) or union officials of the CES (see chapter 7). As one of our interviewees puts it quite clearly: 'The rule of the game is to endeavour not to understand the problems from a national viewpoint, which is very difficult. The ideal choice is a person born in Sweden, having studied in Spain and worked in Germany.' (Interview with a member of the group of political advisers, July 2005.) The promotion of these resources takes on two complementary forms, referring not only to practical skills such as mastering foreign languages, but also to a form of symbolic credit associated with international trajectories and the predispositions they are thought to favour.

Often justified functionally, linguistic skills, and particularly fluency in English, are of paramount importance. The adhesion of the countries from central Europe highlights one of the major effects of the enlargement on working practices: the now overwhelming domination of English as the working language in European institutions. For experts, this involves not only speaking English during most meetings as only a few groups have interpreting systems available or work within DGs wishing to maintain a multilingual meeting framework, but also the obligation to read and write in the language. Being a polyglot, and more specifically being relatively fluent in English, often constitutes a more or less explicit recruitment criterion. If this 'rule' is mentioned by most Commission officials interviewed, often quite bluntly, it is also recognized as a criteria by experts: several interviewees, in particular French experts, thought they owed their appointment to their fluency in English and the scarcity of this skill in their own professional environment.

Some constraints may prevent a strict application of this 'rule'. Such is the case in particular of the groups comprised of 'governmental' experts, which recruit from a pool of national officials with variable opportunities to work in English on a regular basis. However, linguistic resources are essential in practice as they are the condition of being heard and seen as credible by the other members of the expert group. The rare situations where the expert cannot express themselves in English are perceived, by the affected and by his peers, as very handicapping or even embarrassing. Such was the case with a member of the group of experts on sugar, Belgian farmer speaking only French: if his 'practical' legitimacy as a farmer was recognized by his counterparts through his nomination as chairman, he is almost totally cut out from the exchanges during and especially outside the meetings, and cannot partake in the drafting of any document produced by the group.

Fluency in foreign languages is rooted both in national and social backgrounds. They tend to disproportionately disadvantage representatives from Southern Europe and Frenchspeaking countries. Moreover, depending on national contexts, having and acquiring these linguistic skills do not correspond to the same profiles and trajectories. The so-called 'governmental' expert groups, composed of officials from national administrations, are a particularly striking example of this, as they gather individuals with relatively similar education levels and positions, but extremely different levels of fluency in English. It is mainly when confronted with similar situations that some experts embark on intensive learning strategies, thereby demonstrating the importance they ascribe to this skill ('I owe it' to my counterparts in the group, it may 'prove useful later on', are two common expressions in interviews).

Being a polyglot on the other hand is often the characteristic of experts who were raised in multilingual families, and/or whose university or professional trajectories led them to live and work in various countries. These international experiences can take different pathways: 
from a university degree including a year abroad financed by the Erasmus program; a graduate degree from a prestigious British or American university; working in an international environment. These trajectories are particularly present among experts coming from the academia, a profession that is highly structured around the building and maintaining international networks. Among the international experiences recognized as highly legitimate by both experts and Commission officials include experience in different international organisations or international negotiations: in addition to the European institutions properly speaking, those that operate under the control of the United Nations, NATO, and OECD expert committees are mentioned most frequently.

These criteria tend to reproduce, in the arena of expertise, values and hierarchies which prevail more generally in the field of Eurocracy. The proven 'international dimension' of profiles has great symbolic value. In the context of expertise, it is equated to openmindedness but also the universality of the expert's knowledge (Robert, 2010a). It is notable in this perspective that comparative skills are particularly prized: 'Because what we are looking for, at this stage, is expertise ... And of course people with many contacts abroad. Because our major problem, here, is the overabundance of superskilled experts, but who are unable to communicate with other people, let alone with people from other legal systems' (Interview with a member of the DG Home Affairs, April 2008).

\section{Embodying neutrality}

For members of the Commission, certain backgrounds and (professional) trajectories are seen to predispose certain profiles to a greater degree of independence in providing expertise than others. Experts are always associated, to various extents, with one or several identities (national, professional, activist), which should be somehow 'consulted' via their mediation. But they are also expected, on account of their position as experts, and of the necessary 'neutrality' which this role implies, to relinquish, in word as well as in deed, acting as 'representatives' (Bourdieu, 1987), in the meaning of trustee (Pitkin, 1967), of the sectors from which they originate (Robert 2010b). These logics are omnipresent. Therefore even national officials, members of 'governmental expert groups' supposedly 'do not receive any instructions from their respective government. They provide the expert group with their national expertise in a particular field.' (European Commission, 2008)

In this configuration, the (purported) autonomy attached to certain positions takes on significant value. The idea is to select experts whose professional positions theoretically enable them to neutralize conflicts of interests or avoid being captive of the arenas they originate from, thereby strengthening the legitimacy of the group in defining a 'European public interest'. Different categories of actors particularly benefit from these recruitment logics. One of the directors of DG Employment thus stresses in an interview that his directorate is keen on recruiting former 'colleagues' who have retired as a formal guarantee of autonomy of their judgments: 'There is also a pool of independent experts provided by pensioners, those who worked for an administration, a professional union and then left, are not affiliated thereto any longer, but when they belonged to these circles, they represented them, within the committees, notably comitology, and have demonstrated in this framework an authority, a skill that we wish to use further.' (Interview with a member of DG Employment, Social Affairs and Inclusion, November 2004)

The same sort of reasoning applies for a second category of experts: exerts academics who are highly visible ${ }^{5}$ (Gornitzka, Sverdrup, 2010) because they are considered to be more

\footnotetext{
${ }^{5}$ According to the registry of the Commission mentioned previously, close to one third of expert groups include experts belonging to the wider category of the scientists and academics.
} 
'independent': 'Yes, the Commission often resorts to academic expertise and in particular to Belgian expertise, as there are many academics in Belgium who are very independent and on top of that, they are not far away. Consequently, Belgium is an exceptional reservoir of expertise for the Commission. Are academics considered as more independent than the other experts? Certainly so, in particular less linked to particular interests than experts from companies, or administrations, because I forgot to mention the whole expertise from companies and which is quite used by the DG Enterprise and Industry.' (Interview with one of the former directors of the Prospective Unit, J. Vignon, November 2004)

The particular credit ascribed to academics in the expertise procedures may be explained by the fact that they have accrued, sometimes exclusively, specialised know-how considered as useful to the decision-making process. Incidentally, the selection of experts reflects the extent to which certain disciplines, more than others, are perceived to yield sound knowledge of governmental affairs (Robert and Vauchez, 2010): for example, if lawyers and legal advisers are strongly represented in the groups of the DG Home Affairs and to a lesser extent of DG Employment, they have lost ground to economists in the groups of the Bureau of European Policy Adviser.

Their selection rests nevertheless significantly on this presumed independence from private and in particular economic interests, as from national interests, which are just as (if not more) crucial for members of the Commission. This dimension is particularly important in expert groups responsible for examining the transposition and application of European guidelines in the Member States (such is the case in particular of numerous groups of the DG Employment and of the DG Home Affairs) or accompanying the coordination systems of national policies.'To analyse national transposition measures, somebody independent is required. A person with an academic background, a university law professor, is usually the best choice. (...)When I say independent, I mean independent from the Member States and the Commission'. (Interview with a member of DG Home Affairs, October 2006)

As shown by the example of the groups formed around the BEPA and the Commission Presidency (text box), academics are particularly well represented in so-called 'high level' groups, whose work and composition are highly publicised. These profiles of academic experts match those of the Commission officials who recruit them: a common predisposition for international affairs, but also the over-representation of holders of a masters or a $\mathrm{PhD}$ (Beauvallet, Michon, 2010; Georgakakis, de Lassalle, 2007). More generally, the significant presence of actors originating from the academic world within expert groups may be understood as one of the manifestations of the close links which have been woven, since the 1950s, between European institutional elites and the researchers specialised in the European Union studies in different disciplines (primarily law, economy and political science) (Robert, Vauchez, 2010).

Text box $n^{\circ}$ 4: the weight of academic capital, the example of the high level groups of the GOPA and the BEPA

The weight of academic capital can be observed most clearly in the case of the Bureau of European Policy Adviser. The BEPA is an authority enjoying the status of a DirectorateGeneral, directly accountable to President Barroso. It replaced the GOPA (Group of Political Advisers) created by Romano Prodi and the Prospective unit - created by Roy Jenkins and which played a highly visible role under Jacques Delors. During the last two Commissions, these structures have generated and led expert groups which have sometimes played a very public role such as the Sapir group (Peuziat, 2005). All members of the three expert groups associated with the BEPA (the 'political analysis group', the 'economic analysis group', and the 'society analysis group') fulfil or have fulfilled teaching and research positions in academia, which was also the case of the previous groups and structures. Six members of the seven members of the Sapir group were presented as professors. These three groups are accountable to 
'special advisers', working within the BEPA during the presidential mandate, who also originate from the academic world. However, the weight of academic capital is not the exclusivity of the BEPA and can be observed in most groups benefiting from great visibility. For example, the 'Kok task force', named after the former Dutch Prime Minister, Wim Kok, responsible for preparing in 2003 a report on the employment policies in Europe, included five professors among its the eight members.

\section{Multipositionality as an inherent property of expertise}

A more careful examination of the careers and profiles of these academic experts highlights a third inherent property: multipositionality. In addition to their university titles and functions, all the experts mentioned above hold positions in other social and professional spaces. Such is the case for instance of the members of the Sapir group, who are implanted in the academic world, but have also played roles in high-level public service and as consultants. The same goes for the academics of the Kok group, who have also had political careers and high-level national or European public service careers (Maria Joao Rodriguez) or as a consultant for the public and private sectors (Carlo Dell'Aringa). One may also point to the profile of both special advisers of the 'political analysis group' of the BEPA. Loukas Tsoukalis holds a Jean Monnet university chair, is Professor at the University of Athens and the College of Bruges, has been an ambassador, has held functions as a special adviser for several Greek governments, and has also been involved in consulting work for the European Union. As for Dusan Sidjanski, he is the founder and the former director of the Department of political science at the University of Geneva. Known for his Pro-European political commitments and for his positions in the federalist movement, he has also been a consultant for different international organisations.

Multipositionality is not an exclusive to members of 'high level' groups. Its forms vary in relation to the sectors and administrative segments with which the experts are connected. Law professors, lawyers and activists for human rights are closely linked to the DG Home Affairs; professors and researchers going back and forth between consulting activities, academia and roles in the central administration of DG for Employment; academics with political experience work side by side with academics with experiences in the private sector in the BEPA, and so on.

The 'social surface' and the authority associated with these types of career profiles building on different kinds of capitals are obviously in line with the fact that multipositionality is sought after and promoted in the European field (Memmi, 1989, Peuziat, 2005). It is a good indicator of the magnitude of the social resources available to the expert and which can be activated in this context. This may explain why this property is particularly concentrated in the most visible expert groups such as the 'high-level' groups cited above. For example, the Commission official responsible for following the Strauss-Kahn group ${ }^{6}$ justified the choice of Lord Simon in the following terms: 'Lord Simon had been part of several groups, during the Delors era, he was chairman of British Petroleum, he was a member of parliament, he had a way with words, he had good understanding of economic and social phenomena, it was perfect, for an expert practitioner's role.' (Interview with a member of DG Agriculture, July 2005)

\footnotetext{
${ }^{6}$ The Strauss-Kahn group, also designated as the 'Round Table: a sustainable project for European society' was set up with the group of the political advisers accountable to the president of the Commission (GOPA). It was entrusted in 2003 with a reflection on the economic, social and environmental dimensions of the sustainable development.
} 
The preference for multipositioned experts has additional justifications. Specifically regarding academic experts, it touches on the idea that good experts must break from academic standards and practices to meet the expectations of the Commission. The transgression of the rules of scientific work in carrying out practical expertise is one of the fundamental characteristics of this activity (Robert, 2008). University professors unable or unwilling to break with their academic posture are particularly stigmatized: 'There is also here a great distrust against pure academics. I was recruited far more because of my experience in seeking relationships with authorities for promoting research, rather than because of my being a professor. The preconceived idea is that a professor is rigid, does not understand the expectations of a policy maker, is always concerned about his own image and communication, and what he does in the Commission is not so important, and this feeling is very widespread. And the truth is that anyone having dealt with academics will second that opinion.' (Interview with a former member of the group of the political advisers, July 2005)

This representation of academic 'conservatisms' could explain the privileged choice in favour of experts with regular experience outside academia. This is underlined for instance by an official of the DG Home Affairs in charge of a group composed of law professors: 'Most had worked with public authorities so they were aware of the expectations, so they knew that what they were writing had to be relevant to build a policy of prevention, how this knowledge could be relevant for politicians. They knew it was different from academic circles where they just have to talk about their research. [...] Some had already worked with public authorities, as counsellors for institutes or running institutes set up by public institutions... or for international organisations such as the UN I noticed that those who had this background were more accurate. They are not pure academics.'(Interview with a member of the DG Home Affairs, April 2008) Multipositionality is ultimately justified as a legitimate selection criteria because actors having occupied several positions in contrasted social arenas are thought to be better equipped to have the necessary autonomy expected of an expert.

Just as transnational trajectories are associated with open-mindedness, it is thus thought to guarantee a kind of neutrality or 'sense of compromise'. These representations are even stronger where multipositionality goes hand in hand with strong investments in European matters, for example in the case of experts who navigate between teaching, consulting and administrative functions in and around Community institutions or issues. The distance they build with regards to their original national and professional circles conversely implies a social and spatial closeness with European institutions, as we will see in the following section.

\section{European trajectories and expert careers: Expert Groups in the European field}

Regardless of the reasons for which they are selected to join groups, European experts thus share a number of properties. They are thought to be able to promote 'independent' viewpoints and have a sense of compromise which detaches them partially from the types of knowledge or interest they represent. These actors also converge in their common relation to the European institutional field. When observing the trajectories of experts, it appears that they are recruited predominantly among 'colleagues' and/or 'partners' of European institutions. Moreover, there are forms of European careers' which can be identified, either by accumulating expert positions over time, or by reaching other positions in the field through functions in expertise.

\section{'Regular visitors' to European institutions}


Among the resources shared by members of expert groups, familiarity with the European institutions before being appointed as an expert is surely one of the most common. Such familiarity is the product of various professional or activist experiences bringing them in relationship with the field of Eurocracy.

At first sight, this familiarity takes the form of an often in-depth knowledge of the functioning of European institutions and of the relationship of Community policies with their area of expertise. European civil servants and experts agree that expertise is only useful if the constraints and possibilities of actors to formulate concrete and defendable propositions are taken into consideration. This requires a mastery of Community institutions active in the given sector, as well as realistic knowledge on the apportionment of skills, the legal bases and the decision-making procedures governing it. This provides a relatively accurate picture of the positions of the main actors on the discussed issue, of the major lines of opposition and possible power struggles, and a sense of the margins that departments asking for the expertise dispose of.

In certain configurations of expert groups extremely close to interest groups, the organisations will thus send, when they can, two experts: one being an activist belonging to the organisation who covers the more technical side of issues under discussion, and the other, a permanent member of the Brussels office with many contacts with European institutions, and often holding a degree in European studies. For example, the COFACE (Confederation of family organisations of the European Union) is represented in a 'high level' expert group by one of its permanent employees of the Brussels office and by the director of one of its member organisations, a Belgian association, based in Brussels, representing families of polyhandicapped children. The latter is not devoid of skills adapted to Community arenas. Due to the activity of his association but also its geographic proximity with the institutions, this representative had already been implicated in expert groups from the very start of consultations on handicap in the 1990's.

The means to acquire these attributes and skills are varied. Most experts share some, at least theoretical, knowledge of the way the UE works in their sector. This knowledge is often partially the product of experience and is coupled with more practical knowledge of the policies and institutions. The existence of working relationships prior to accessing positions of expertise, is indeed a second important dimension of the 'familiarity' of experts with the European institutions.

Text box $\mathrm{n}^{\circ}$ 5: The importance of 'European experiences' for becoming experts The example of the consultative group on the integration of the ethnic minorities

The composition of the 'High level consultative group on the integration of the underprivileged ethnic minorities in society and in the labour market' illustrates the importance of personal contacts with Commission officials. Asked about the criteria which governed the selection of the members on this group which centred discussion on the Rom community, the administrator of the Commission started by underlining the diversity of the members of the group at length and noted that interest and prior knowledge of the situation of the Rom minority was not the common denominator, to say the least. It is only when asked about how the members were identified, that he went on to explain: 'we knew all ten of them, because each of them, in the past, had collaborated with the Commission in various contexts.' (Interview with a member of DG Employment, June 2007) The careers of the experts testify to the density and the variety of these prior forms of collaboration. The Finnish expert, Tarja Summa, presented as a 'former mediator for refugees' has held important functions with the Finnish government during the Finnish presidency of the UE. Ilze Brands Kehris, director in Latvia of a centre for human rights was a former member of the management committee of what has since become the European agency for fundamental rights. Bashy Quraishy, the Danish president of the European 
network against racism, has long maintained close relations with different departments of DG Employment. José Manuel Fresno was director general of the Luis Vives Foundation, which promotes the third sector and the social economy in Spain, and which is funded by the European social fund and benefits from strong recognition in the Commission. Jarmila Balážová, a journalist and activist in the Czech Republic for the defence of the Rom minorities had close relations with Commissioner Vladimir Spidla. Finally, István Sértö-Radics, presented as the mayor of a small town in Hungary, Uszka, within which the Rom minority is particularly present, is also a member of the Committee of the Regions of the European Union.

This example illustrates the existence of several logics. A first type of experience includes all forms of temporary contracts offered by the Commission to external operators. Such is the case, in particular, of experts from the academic world, almost all of whom have had prior experiences in contract research with the European administration. Outside the FPRDs, certain departments, such as DG for Employment and DG for Home Affairs commission studies on a very regular basis, where authors are subsequently invited to join the expert group. These cumulated activities with expertise functions can also be observed in relationships with interest groups. Some are frequently called on to be part of the groups, and are at the same time beneficiaries of Community funds and privileged partners of Commission departments within the framework of other types of consultations (forums, Internet-based consultations, and so on). In these instances, 'European capital' is less a personal than a collective resource.

A second point of contact between Commission officials and 'their' experts takes place outside the institutions. This may happen at the 'periphery' via think tanks, and more generally arenas that promote relations between the academic world and European political and administrative elites. These meetings may also take place in other international arenas, such as OECD committees. As an illustration, we can take an example from the sector of data protection. An economist by training, Marie George is member of the group of the European control authorities in charge of data protection (or group 29, named after the article of the 1995 guideline). After a brief career in banking then in the INRIA (National Institute for Data-processing and Automation Research), she joined the CNIL (French National Commission for Data-processing and Liberties) in 1979. She was delegated from the CNIL to the Commission between 1990 and 1995 and was active in the preparation of several important European guidelines for data protection. George returned subsequently to the CNIL, where she was appointed as division head of European \& International Affairs and Prospective. In parallel during this period, she was member of several groups organized by the Council of Europe and the OECD. Finally, experts originating from the national administrations have frequently been members of the comitology committees. It is common that a group of experts composed of national officials overlaps, totally or partially, a comitology committee, meeting twice the same day in two different configurations.

\section{'Expert careers': expertise as a cumulative resource}

If most experts are thus recruited among the professional networks gravitating around the Commission, this element is often complemented by prior experience. 'And there is also an unwritten tradition. When we must form a group, we look at the groups formed in the past on the same subject. We ask how they have operated, who is a talented writer and who is not, how they behave in the group, there is a whole formal but also informal process for judging, storing,, accumulating the experience of the groups who have already worked on that subject and for saying, for this particular aspect, that the contribution of that lady was extremely useful. And consequently, that lady will be given a second chance.' (Interview with a member of the group of political advisers, July 2005) As illustrated by this quote, adhering to 
a set of behavioural standards (sense of compromise, relation to political representation) is recognised both as a central skill, by sponsors as well as by expert peers, and rewarded precisely by the possibility of cumulating, sometimes simultaneously, most often successively, expertise positions ${ }^{7}$. In other words, a successful past experience as an expert is a self-reproducing capital. The significance ascribed to prior experience in the recruitment of experts thus reinforces these codes of conduct, but it can also be observed through the trajectories of these actors in the field of European expertise.

Without going into too much detail (Robert, 2010b), two overarching types of norms can be mentioned. A first set of prescriptions or expectations is governed by the desire neutralize links between their institutional positions and their positions in discussions. Recruited for their representativity, possibly on account of belonging to an organisation or an administration, the expert should however not act explicitly as 'representing' a particular viewpoint. If the practices of the experts are not insulated from outside interests, great care is taken for positions not to be seen as dependant on 'outside' interests. Experts are thus expected to give up any explicitly political or national argument, and base their arguments on 'solid' knowledge bringing them to often resort to a technical register to state opinions with an appearance of neutrality.

A second type of norm regulating the exchanges within the groups is the 'sense of compromise" which is expected. Taking advantage of their familiarity with the Community political and institutional codes of conduct, they must not only be able to perceive what is negotiable - within the group, or for the Commission with regard to the Council and the Parliament -, but also to adjust their positions in light of these constraints. Even more than in other European arenas, the participants of expertise procedures are invited to give the priority to compromise within the group over the firm defence of their own viewpoints ${ }^{8}$. As stated by a female Commission official: 'A good expert is someone who has no strong individual project. [...] to make a group work, nobody should dominate, even if it is the most intelligent person. If someone has very strong convictions, they should not be placed in a group of experts.' Experts who cannot concede defeat discreetly when the power struggle bends against them will be judged negatively. Those who, by their discourses or by their attitudes, highlight conflicts of interest and antagonisms in the group, stand little chance of being asked to join another expert group in the future.

These norms are common in other Community circles. Such is the case for instance of the controlled usage of the reference to national interest, of strategies for suppressing tensions and avoiding open conflicts which has been documented in studies on working groups of the Council (Lewis, 2005; Juncos, Pomorska, 2006), the comitology committees (Eichener, 1992; Krapohl, 2003), in the European parliament (see chapter 1) and among officials of the Commission (Robert, 2005). Through the similarity of the practices expected of experts with those spanning the entire field of Eurocracy, it can be seen why prior professional experiences in connection with European institutions, and most particularly in expert groups, appear particularly propitious to recruitment. They are indeed key moments of socialization (Robert, 2010b), and of learning the 'know-how' and types of 'behaviour' which then promote a continued access and success in the positions of expertise.

\footnotetext{
${ }^{7}$ This leads us to consider expert groups as places of socialization. On this aspect as well as the contents of these norms, their political aspects and the way they contribute to delineate and direct the work of the experts, see Robert (2010b).

${ }^{8}$ This posture is asserted even in official documents, as illustrated by one of the recommendations made to the administrators and to their experts in a document leading up to the White Book on governance: 'If the participants only attend the meetings to expose their own viewpoint without being open to the others', there is a considerable waste of important information and the plurality does not translate into learning, but simple positioning.' (European Commission, 2001, p. 9)
} 
As the administrative data on expert groups are highly incomplete, it is difficult to measure the ability to conform to expectations with precision. From the sample analysed in the qualitative part of our survey, it seems more than half, often two thirds of experts are approached to participate either in the group succeeding theirs, or to another expert group. An example of a typical 'repeat player' is that of an academic expert for DG Employment. This academic participated in projects financed on FPRD funding in the 1990s. Via the network formed around these European projects, he was noticed and approached by the departments of the Commission in 2000 for writing a report on the policies to fight poverty in his country. When three years later, DG Employment wished to set up a group of experts capable of following the developments of an open method of coordination procedure in this field, he was invited to join. Composed of 27 members, the group replaces on average two members every year, mainly people who are too frequently absent or not meeting expectations. Our expert was one of those who stayed on. After three years, the departments chose to keep a group but with a slightly form different, in particular by integrating experts co-opted their peers. Our expert was approached by the Commission to be part of the new team, and was appointed again in 2007. A few years before retirement as director of a department in a prestigious University, he did not rule out extending his activity as a European expert beyond 2010. (Interview with a member of the network of independent experts on social inclusion, March 2009)

Among career trajectories marked by an accumulation of position, certain expert 'careers' take on even more specific forms. The trajectories may be so sustained over time and that certain actors stand out as indisputable figures in their fields of intervention and beyond. This translates frequently into participation in groups supervised by distinct departments, and even by different directorates-general. The probability of an expert being recognised and approached beyond his first network of interlocutors in the Commission thus provides a valuable indicator of the longevity of an expert career. Such is the case of Elspeth Guild, a well-known figure for her legal activism on migration issues in Europe. A Professor at the University of Nijmegen, a member of the CEPS (Centre for European Policy Studies) think tank, she was also a partner in a law firm (Kingsley Napley in London). She has not only contributed to several FPRDs, but has also been an expert on several occasions and, since the beginning in the 90s, for DG Employment (within the framework of the observatory of the free circulation of workers) and DG Home Affairs via her participation in the Odysseus network.

Moreover, multipositioned experts can use their roles in European expertise as career springboards towards more prestigious groups or more influential or lucrative careers. The trajectory of André Sapir, a economics professor at the Free University of Brussels is a good example. A PhD holder form John Hopkins University, Sapir participated in two European think tanks (Bruegel and the CEPR). Jointly with his different academic and consulting activities, he took on expertise functions for the DG Economic and financial affairs, from 1990 to 1993 then again from 1995 to 2001. He become an economic adviser to Romano Prodi upon his election, then was appointed in 2002 President of the 'high level' group in charge of reviewing all economic policies of the UE. The group produced the influential report entitled 'An agenda for a Growing Europe', better known as the Sapir report in 2003. Under Barroso, and for the whole duration of the first mandate, he was president of the group of experts on the economy accountable to the BEPA. During the same period in 2005 he was approached to join a high level group composed of recognised economists and reported to Commissioner J. Potočnik for advising him on the Lisbon strategy in the field of research.

Other indications on these mechanisms of selection and promotion are provided by Jean-Michel Eymeri-Douzans in a recent paper (2010) reflecting on his career as a European expert. Initially a member of the European Institute for Public Administration of Maastricht, which the Commission contacted regularly for research reports, he was 'noticed' by the unit 
head of the DG Information society, for which he prepared three documents in 1999. He then took part, always for the same departments, in various juries, conferences, etc. Later, he was involved in various FCRD research projects and became a regular collaborator for DG Research, who entrusted him with complementary expertise missions. These joint activities for the DGs for Research and Information society notably led in 2003 to his integration into a group of eight experts formed for advising Commissioner Erkki Liikanen in the preparation of the 'eEurope Action Plan 2005' which was adopted during the European Council in Seville.

The promotions may also, and sometimes jointly, take the form of new responsibilities within the framework of the group. They may for example be appointed chairpersons for the expert group. These are honorific functions, but they provide a certain notoriety, if only because the groups and the reports are named and once publicised, after the President. They also offer, in a number of cases, leadership resources such as determining the order of speakers, determination the agenda, and preparation of documents in close collaboration with the Commission. These experts may also be involved in the recruitment of peers, either as informal advisers to the Commission within the framework of peer review procedures, or by creating a network of European counterparts around themselves to influence power relations within a group. Two examples can illustrate such processes.

A junior researcher in a research Institute in Luxemburg, $X$ had been involved since the end of the 1990s in different European projects on statistical indicators related to social protection. He wrote several reports for various international organisations, and was involved in two presidencies of the UE regarding these issues as a political adviser. He had also regularly represented his government in certain arenas. He was then approached at the beginning of the 2000s by a member of DG Employment who sought to create a new group of experts on social inclusion. At the end of the mandate, the departments wished to replace the group with a network of independent experts and approached $\mathrm{Y}$ informally asking him to constitute, with another colleague, a network which he could coordinate. Shortly thereafter, Y was appointed as president of a more selective and more visible group, a task force entrusted with generating a report on child poverty, addressed to the Commission and the Member-States. (Interview with a member of a group of experts of the DG Employment, February 2005)

Holding a $\mathrm{PhD}$ from the University of New York, a specialist of the sociology of science, Helga Nowotny had taught in several universities in Europe (Austria, France, Switzerland, Hungary). She had also held high-level functions in the European Science Foundation since the 1980s, and she was a member of the board of administration of several research institutions in Europe. From the second half of 1990s onwards, she worked as an expert for DG Research, initially as an evaluator for FPRD projects. She was then called upon to participate in the expert group entrusted with preparing the guidelines for the 'Human and social sciences' section of FPRD programmes. In 2001, she was offered the presidency of a new expert groups entrusted with reflecting, with academics and industrialists, on the future of the Community research policy (ESTA then EURAB - European Union Research Advisory Board). She was appointed vicepresident of the newly implemented ERC (European Research Council) whose creation had been a central recommended of EURAB.

The analysis of these different illustrative trajectories demonstrates the weight of prior experiences for accessing other, often more prestigious functions of the same type. Such trajectories also highlight the contribution of experts to these recruitment procedures. Among the forms of retribution that are offered to more regular experts, recruitment tasks are 
significant, and 'regulars' tend to co-opt peers who share their types of resources and profiles. When forming networks for instance, they tend, for various reasons, to approach former colleagues. An edifying example is provided by the testimony of an expert who related that at the end of the mandate of his group, he was approached by no fewer than five members of the group, each having been asked to help the Commission in the constitution of a network of experts which was to replace the expert group. Beyond their similarities, the careers and profiles analysed in this article also serve to remind us that all expert-related experiences are not reproduced with the same efficiency and that the rewards for investment in expert groups can vary. It has been argued above that they are closely related to the capacity of the expert to conform with the unwritten rules governing work in the groups (Lagroye, Offerlé, 2010; Robert, 2010a). The future career development, as well as the succession of positions remain dependant on the interplay between on the one side personal resources (social surface, scientific renown, political and institutional networks, professional status, nationality, and so on) and the other side, their relevance in different institutional spaces.

\section{After expertise: possible reconversions to permanent European careers}

The analysis of these trajectories leads us to mention, more generally, the question of reconverting European capitals built on expertise-related experiences into European careers. If the expert's function remains, by definition, a position that is not only temporary but also non-exclusive and unpaid, it is not deprived of effects on the professional careers of those fulfilling such positions. Based on the experts studied in this investigation, two observations to be formulated.

It may first of all be underlined that the forms of 'Europeanization' promoted by unpaid expertise may become lucrative when converted in the experts' original professional arenas. This can explain why such time consuming and unpaid functions are attractive to many. In addition to the prestige associated with the title, having served as an expert for the European Commission is a golden opportunity for acquiring a collection of practical and symbolic resources. An expert position can offer a first working experience in an international environment, where the aim may be simultaneously to perfect and to validate linguistic skills (working in English), furthering knowledge of a given Community policy, or to compare their own national practices with other nation's and assert a 'European' viewpoint. Belonging to expert groups also gives access to relational resources, as it provides the opportunity to form or consolidate valuable networks at the European level with peers. This is for example the case for a lecturer in law whose participation in an expert group enabled him to open new fields of research in comparative law. He mentioned in particular access via the group to foreign data and to establish a working relationship with European colleagues with whom he could more easily put together international research teams necessary for obtaining European research funding. For another expert, a senior scientist in a prestigious university, it was the 'European dimension' conferred to his CV by his six-year experience in a group of experts, associated with his commitment in research projects financed by the Commission, which contributed to his being appointed head of his department.

The establishment of close links with European institutions promoted by the multitude of expert positions also takes on more concrete forms. The most striking cases are those of actors who, after completing one or several mandates, were offered positions in the departments for which they had served as experts. Among the situations encountered during our survey, one can mentioned researchers positions within DGs open to academics on leave of absence for one or more years, the national experts positions offered to national civil servants, or temporary contracts of various lengths within the Commission. To this list should also be added positions offered in agencies tightly linked to the Commission. This is the case 
of networks of experts financed by calls for tender for a three-year duration, in which the contract coordinators and holders are almost always former expert members of the group having paved the way for the network. It is also the case of certain agencies, for example the European agency for fundamental rights, which also are the heirs of former networks or expert groups and provide the backbone of executive members.

Even if all these trajectories do not culminate in a permanent career within the Commission a final reconstruction of an expert trajectory provides a good illustration of the opportunities offered by this type of experience. A regional economy and economic geography professor as well as a director of a Research centre in the University of Ancona, Y was approached on several occasions by the Prospective Unit. Shortly after the term of this first contract, she was approached to become a temporary agent in the GOPA where she was entrusted in particular with coordinating the activity of high level groups initiated by Romano Prodi (Sapir group, Strauss-Kahn group, etc.). Renewed twice, her temporary contract (three years) expired in a context where the structural reorganisation and the change in direction did not offer the same opportunities for her profile. Her contacts and her collaborations with DG Agriculture then opened to her the perspective of a new contractual position over several years, where she hopes to finish her career. (Interview, July 2005)

\section{Conclusion}

Forming a heterogenous world with blurred contours, the members of the expert groups of the European Commission however share a number of common practices and properties: predispositions to an international environment, academic capitals, experience in negotiation and a sense of compromise. These properties (like the symbolic value conferred on experts) are not so remote from those held and asserted by other more central populations of the European field, like MEPs, lobbyists and European civil servants. These groups tend to recruit actors who already are 'intermittent' actors in the European political field. Finally, the expert's function, although temporary by definition, enables a number of its holders to become 'semi-permanent' participants in the field of Eurocracy (see the conclusion in this volume). Thus, recruitment strategies and criteria, like the career patterns of the experts themselves, seem to contribute to 'bringing experts and recruiters closer', and to transform more generally the field of European expertise into an arena highly structured by, and dependant on, the specific rules and practices of the European institutional space.

These observations underline the importance of careers and social backgrounds in studying the European polity (Georgakakis, 2009). As emblems of the new 'European governance' (European Commission 2001a, 2001b), expert groups are indeed in the official discourse of the institutions and especially of the Commission, portrayed as one of the tools enabling the participation of all 'interested parties' in the formulation of public policy. Consequently, it supposedly provides decision makers with efficient and fair means of policymaking requiring a balanced synthesis of these various points of view. This vision is widely shared by the actors themselves, including the biggest detractors of expert groups as they function, such as the members of the Alter EU coalition and of the Corporate EU Observatory. Centred on the reduced representation, numerically speaking, of NGOs in comparison with the weight of industry, the criticisms of these watchdogs paradoxically strengthen rather than question one of the essential postulates driving these government schemes: the idea that the gathering, under the same authority, of individuals from varied 'walks of life' (national, occupational, sometimes political) would suffice to guarantee a multifaceted operation allowing for a definition of a European interest to emerge. In contrast, the investigation presented in this chapter invites caution on this point. It shows first of all that the diversity of the statuses and of the backgrounds of the actors gathered in the groups 
does not prevent them from also sharing a collection of similar resources, experiences, possibly aspirations, which may have the same structuring effect for defining their positions as their most visible identities. It also underlines that due to the unequal distribution of these resources, crucial for access as well as success in this role, getting a seat at the table of a group will never guarantee an expert the possibility to contribute to the construction collective opinions and even less to participate with his peers possessing more adjusted resources on an equal basis (Jobert, 2003 ; Padioleau, 2000).

\section{References}

Alter EU. (2009) A captive Commission : the role of the financial industry in shaping EU regulation

Friend of the Earth Europe. (2009) Whose views count? Business influence and the European Commission's High Level Groups

Alter EU. (2010) Bursting the Brussels' Bubble

Alter EU. (2012) Who's driving the Agenda of DG enterprise and industry

Beauvallet, W. and Michon, S. (2010) L'institutionnalisation inachevée du Parlement européen, Politix. n. 89: 147-172.

Bourdieu, P. (1987), Choses dites, Paris: Minuit

Dauvin, P. and Siméant, J. (2004) ONG et humanitaire. Paris: 1'Harmattan.

De Maillard, J. and Robert, C. (2008) Gouvernement par comités. In: C. Belot, P. Magnette and S. Saurugger (eds.) Science politique de l'Union européenne. Paris: Economica.

European Commission. (2001a) Democratising Expertise and Establishing Scientific Reference System. Report of the Working Group for White Paper on Governance

European Commission. (2001b) European governance. A White Paper, Brussels, COM (2001) 428 final

European Commission (2002a) Guidelines on the collection and use of expertise by the Commission. C (2002) 713

European Commission (2002b) Simplifying and improving the regulatory environment. Action plan. COM (2002) 278

European Commission. (2005) Communication of the Commission. Managing the expert groups of the Commission. Horizontal rules and public registry. C (2005) 2817.

European Commission. (2008) Page of the Secretariat-General dedicated to the expert groups: http://ec.europa.eu/transparency/regexpert/index.cfm, visited on 1 September 2008.

European Commission. (2010) Rules for Commission Expert Groups. C(2010) 7649 final

European Commission. (2012) Page of the Secretariat-General dedicated to the expert groups: http://ec.europa.eu/transparency/regexpert/index.cfm, visited on November 2012

Eymeri-Douzans, J.-M. (2010) Ce que faire l'expert pour la Commission veut dire. Essai d'auto-analyse d'une trajectoire de socialisation In: H. Michel and C. Robert (eds.) $L a$ fabrique des Européens. Processus de socialisation et construction européenne. Strasbourg: Presses universitaires de Strasbourg, pp. 287-312. 
Fouilleux, E. Maillard, (de) J. Smith, A. (2004) Les groupes de travail du Conseil : nerf de la production des politiques européennes? In: Lequesne C., Surel Y. (dir), L'institutionnalisation de l'Union européenne, Paris: Presses de Sciences Po

Georgakakis, D., de Lassalle, M. (2004) Les directeurs généraux de la Commission. Premiers éléments d'une enquête prosopographique. Regards sociologiques, 27 \& 28

Georgakakis, D., de Lassalle, M. (2007) Les très hauts fonctionnaires de la Commission européenne : genèse et structure d'un capital institutionnel européen. Actes de la recherche en sciences sociales, nos. 166-167: 38-53

Georgakakis, D. (2009) The Historical and political sociology of the EU: a uniquely French methodological approach? French Politics, 7(3-4): 437-455

Georgakakis, D. and Weisbein, J. (2010) From above and from below : a political sociology of european actors. Compararative European Politics, 8 (1): 93-109.

Georgakakis, D. (2010) Tensions within Eurocracy. A socio-morphological view. French Politics, 8:116-144

Gornitzka, A. Sverdrup, U. (2008a) Who are the experts? The informational basis of EU decision-making. Arena Working Paper, Center for European Studies, University of Oslo, http://www.arena.uio.no/publications/working-papers2008/papers/wp08_14.pdf

Gornitzka, A. Sverdrup, U. (2008b) Who Consults? The Configuration of Expert Groups in the European Union. West European Politics 31(4): 725-750

Gornitzka, A. Sverdrup, U. (2010) Enlightened decision making ? The role of scientists in EU governance. Politique européenne, 3(32): 125-149

Gornitzka, A. Sverdrup, U. (2011) Access of Experts: Information and EU Decision-making. West European Politics, 34(1): 48-70

Jobert, B. (2003) Le mythe de la gouvernance dépolitisée In: Favre Pierre (eds), Être gouverné. Études en l'honneur de Jean Leca, Paris: Presses de Sciences Po

Juncos, A.E. and Pomorska, K. (2006) Playing the Brussels game: Strategic socialisation in the CFSP council working groups. European Integration On Line Paper 10(11)

Krapohl, S. (2003) Risk regulation between interests and expertise: the case of BSE. Journal of European Public Policy 10(2): 189-207

Lagroye, J. Offerlé, M. (eds.) (2010) Sociologie de l'institution, Paris: Belin

Larsson, T. (2003) Pre-cooking - The World of Expert Groups in the European Union. A report for the Swedish Finance Minister.

Larsson, T. and Murk, J. (2007) The Commission's expert groups. In: T. Christiansen, T. Larsson and G. Schaeffer (eds.) The Role of Committees in the Policy Process of the European Union. London: Ashgate.

Lewis, J. (2005) The Janus face of Brussels: Socialization and everyday decision making in the European Union. International Organization 59: 937-971.

Memmi, D. (1989) Savants et maîtres à penser. La fabrication d'une morale de la procréation artificielle. Actes de la recherche en sciences sociales, 76-77: 82-103.

Michel, H. (2007) La 'société civile' dans la 'gouvernance européeenne'. Eléments pour une sociologie d'une catégorie politique. Actes de la recherche en sciences sociales, 166-167: $30-37$. 
Nay, O. and Smith, A (2002) Le gouvernement du compromis. Courtiers et généralistes dans l'action publique. Paris: Economica

Padioleau, J.-G. (2000) La gouvernance ou comment s'en débarrasser. Stratégies de corruption. Le Banquet

Peuziat J.-P., 2005, La politique régionale de l'Union européenne, entre expertise et réforme (The regional policy of the European Union, between expertise and reform), Paris, L'Harmattan

Peuziat, J.-P. (2005) La politique régionale de l'Union européenne, entre expertise et réforme. Paris:L'Harmattan.

Pitkin, H. (1967) The Concept of Representation. Berkeley, CA: University of California Press.

Robert, C. (2005) Doing politics and pretending not to. The Commission's role in distributing aid to Eastern Europe. In: A. Smith (ed.) Politics and the European Commission. Actors, Interdependence, Legitimacy. London: Routledge.

Robert, C. (2008) Expertise et action publique. In: O. Borraz and V. Guiraudon (eds.) Politiques Publiques Vol. 1. Paris: Presses de Science Po.

Robert, C. (2009) Entre expertise et consultation: les légitimités paradoxales des groupes d'experts européens. In: M. Camau and G. Massardier (eds.) Démocraties et autoritarismes. Fragmentations et hybridations des régimes. Paris: Karthala.

Robert, C. (2010a) Les groupes d'experts dans le gouvernement de l'Union européenne. Politique européenne 32: 7-38

Robert, C. (2010b) Devenir 'expert' auprès de la Commission européenne: une question de savoir-faire? Sens du jeu institutionnel et socialisation politique. In: H. Michel and C. Robert (eds.), La fabrique des Européens. Processus de socialisation et construction européenne, Strasbourg: Presses universitaires de Strasbourg, pp. 313-346.

Robert, C. and Vauchez, A. (2010) L'académie européenne. Savoirs, experts et savants dans le gouvernement de l'Europe. Politix 23(89): 9-34.

Vassalos, Y. (2008) Secrecy and corporate dominance. A study on European Commission Expert Groups. Brussels, Belgium: Alter EU.

Wagner, A.-C. (2004) Syndicalistes européens. Les conditions sociales et institutionnelles de l'internationalisation des militants syndicaux. Actes de la recherche en sciences sociales no. 155: $13-33$. 